\title{
COMPARISON OF FIELD AND LABORATORY MODELS OF THE LOAD BEARING CAPACITY IN COFFEE PLANTATIONS
}

\author{
Comparação de modelos de capacidade de suporte de carga do \\ solo de campo e laboratório em plantações de café
}

\author{
Piero Iori $^{1}$, Moacir de Souza Dias Junior ${ }^{2}$, Ayodele Ebenezer Ajayi ${ }^{3}$ Paulo Tácito Gontijo Guimarães ${ }^{4}$, \\ Paula Sant'Anna Moreira Pais ${ }^{2}$, Maria Luiza de Carvalho Andrade ${ }^{2}$
}

\begin{abstract}
Precompression stress is an important property for assessment of tropical soil structure sustainability and is often determined in laboratory tests. The objective of this study was to compare the load bearing capacity models obtained with controlled moisture in laboratory and those obtained with natural field moistures determined a long one year. The evaluation of soil structural sustainability follows four distinct steps: soil sampling in the field, uniaxial compression test of the samples in the laboratory, determination of precompression stress and estimation of the load bearing capacity models. Laboratory estimates of precompression stress were obtained from moisture controlled in laboratory and from natural moisture determined in a field a long one year. In this process, the soil samples were saturated by capillarity with distilled water in laboratory, and after 48 hours, the samples were air dried to obtain the different moisture contents. Then, the precompression stress was determined for this both conditions. To verify if the load bearing capacity models obtained with controlled moisture in laboratory may represent the load bearing models obtained with natural field moisture, these models were compared using the homogeneity test procedure. It was observed that $75 \%$ of field models analyzed were similar to the laboratory models. Thus, due to the similarity on the load-bearing capacity models obtained using natural (field) or controlled (laboratory) moisture contents, the assessment of the soil structure sustainability can be done using both methods.
\end{abstract}

Index terms: Agricultural traffic, Coffea Arabica L., homogeneity test, precompression stress.

\section{RESUMO}

Pressão de pré-consolidação é uma importante propriedade na avaliação da sustentabilidade estrutural do solo e é determinada em testes de laboratório. Neste estudo, objetivou-se comparar modelos de capacidade de suporte de carga obtidos com umidade controlada em laboratório e com umidade natural de campo ao longo de um ano. A avaliação da sustentabilidade estrutural do solo ocorreu em quatro etapas: coleta de amostras de solo indeformado, ensaio de compressão uniaxial das amostras em laboratório, estimativa da pressão de pré-consolidação e obtenção dos modelos de capacidade de suporte de carga. As estimativas da pressão de pré-consolidação de laboratório e de campo foram obtidas com umidades controladas em laboratório e com umidade de campo, respectivamente, ao longo de um ano. No laboratório, a saturaçaõ das amostras se deu por capilaridade, com água destilada e depois de 48 horas, essas amostras foram secas ao ar para obter diferentes valores de umidade. Em seguida, realizou-se o ensaio de compressão uniaxial dessas amostras e a pressão de pré-consolidação foi determinada para as duas condições aqui proposta. Para verificar se os modelos de capacidade de suporte de carga com umidade controlada em laboratório podem representar os modelos de capacidade de suporte de carga de umidade natural, esses modelos foram comparados utilizando o teste de homogeneidade de dados. Observou-se semelhança em $75 \%$ dos modelos de umidade de campo com modelos de umidade controlada em laboratório. Portanto, em razão da similaridade, a análise da sustentabilidade estrutural do solo pode ser feita por ambos os modelos de capacidade de suporte carga, ou seja, modelos obtidos com amostras de solo com umidade natural (campo) ou com umidade controlada (laboratório).

Termos para indexação: Tráfego agrícola, Coffea Arabica L., teste de homogeneidade, pressão de pré-consolidação.

\section{(Received in december 11, 2012 and approved in february 19, 2013)}

\section{INTRODUCTION}

When soil is under stress a characteristic relationship between compressive stress and volume change can be used to define some important soil physicomechanical properties (GREGORY et al., 2006). One of these properties is the precompression stress. The first calculations of precompression stress, a graphical estimation procedure were described by Casagrande (1936). This author defined precompression stress as the maximum past vertical effective stress applied to the soil and correlated it to the change in slope of a curve of void ratio versus logarithm of the vertical effective stress obtained

\footnotetext{
1Universidade Federal de Lavras/UFLA-Departamento de Ciência do Solo/DCS - Cx. P. 3037-37.200-000 - Lavras - MG - Brasil - pieroiori@hotmail.com 2Universidade Federal de Lavras/UFLA - Departamento de Ciência do Solo/DCS - Lavras - MG - Brasil

${ }^{3}$ Federal University of Technology - Department of Agricultural and Environmental Engineering, Akure - Nigeria

${ }^{4}$ Empresa de Pesquisa Agropecuária de Minas Gerais/EPAMIG - Centro Tecnológico do Sul de Minas/CTSM - Lavras - MG - Brasil
}

Ciênc. agrotec., Lavras, v. 37, n. 2, p. 130-137, mar./abr., 2013 
from a one-dimensional consolidation test (LEROUEILL; SAMSON; BOZOZUK, 1983). This approximation represents an elasto-plastic model (KELLER et al., 2011), with the precompression stress representing the transition point between the secondary compression curve (elastic deformation) and the virgin compression curve (plastic deformation). The secondary compression is generally agreed to reflect the soil management history.

Several methods had been proposed by various researchers in defining the point where the reversible elastic failure becomes irreversible plastic deformation in soil compression curves (CASAGRANDE, 1936; DIAS JUNIOR; PIERCE, 1995; ARVIDSSON; KELLER, 2004; GREGORY et al., 2006). The interest in accurate definition of this point could be related to its wide application in understanding soil structure dynamics. According Dias Junior and Pierce (1995), most of the methods proposed by earlier researchers for the estimation of precompression stress were not easily replicable and some involves subjective judgment. In trying to eliminate the subjective judgment, thereby facilitating accurate estimation, these authors compared five methods with the Casagrande graphical estimation procedure and thereafter developed a spreadsheet procedure for estimating precompression stress for either saturated or unsaturated soil based on data from uniaxial compression tests. The Casagrande method is widely agreed as the standard. Following their work, a number of authors had also evaluated different methods of estimating precompression stress (DIAS JUNIOR; PIERCE, 1995).

The shape of the soil compression curves is largely influenced by the moisture content (DIAS JUNIOR; PIERCE, 1995). Considering this interrelationship in the shape of the soil compression curves and moisture, these authors suggested a soil load bearing capacity (LBC) model based on the soil compression curves, obtained for different moisture conditions. The LBC model may be used to estimate the maximum pressure that can be applied to the soil in order to avoid structural degradation and could also be used to estimate the pressure that roots will need to exert in order to overcome soil strength. This model takes the general form: $\sigma_{\mathrm{p}}=10^{(\mathrm{a}+\mathrm{b} \theta)}$, were, $\sigma_{p}$ is precompression stress $(\mathrm{kPa}) ; \theta$ is volumetric soil water content; $a$ (linear coefficient or intercept) and $b$ (angular coefficient) are empirical parameters for model adjustment.

As one of the most important assessment tools of structure sustainability of the tropical soils, LBC models can be used to compare the effect on soil structure, varying soil managements (DIAS JUNIOR et al., 2005; ARAUJO-
JUNIOR et al., 2011; PIRES et al., 2012), different land uses (IORI; DIAS JÚNIOR; SILVA, 2012), and as indicator in evaluating soil vulnerability to compaction (AJAYI et al., 2010), and in the assessment of alleviation of the soil structure in degraded land (DIAS JUNIOR et al., 2007), among others.

In practice the $\mathrm{LBC}$ model of soils are obtained from samples with moisture controlled in laboratory by natural drying in the laboratory or varying water tensions. The samples are then used in uniaxial compression test (MARTINS et al., 2012; IORI et al., 2012; PIRES et al., 2012). Hamilton and Crawford (1959) noted that in the laboratory procedure some alterations in results often occur. They noted that stress reduction or changes in principal stress ratio for example, will occur due to soil sampling and specimen preparation and this is probably responsible for most of the disagreement between laboratory results and field observations. In the laboratory the different moisture contents are obtained artificially, whereas models with natural moisture in temporal terms are scanty in the literature. Thus, the objective of this study was to compare the load bearing capacity models obtained with controlled moisture in laboratory and those obtained with natural field moistures determined a long one year.

\section{MATERIAL AND METHODS}

The study was conducted in coffee plantations located in the Três Pontas County, South of Minas Gerais State, Brazil (2426' S; 4749' W, altitude of 905 meters). The region is characterized by predominant relief of undulating topography. The climate according to Koppen is Cwa, that is, altitude tropical, with an average annual temperature of about $18^{\circ} \mathrm{C}$. The average annual rainfall is $1,300 \mathrm{~mm}$ with the highest concentration in the months from December to February. The soil of the study area was classified as a Red-Yellow Latosol (Oxisol) clayey texture (EMPRESA BRASILEIRA DE PESQUISA AGROPECUÁRIA-EMBRAPA, 2006) with $510 \mathrm{~g} \mathrm{~kg}^{-1}$ of clay, $200 \mathrm{~g} \mathrm{~kg}^{-1}$ of sand and $290 \mathrm{~g} \mathrm{~kg}^{-1}$ of silt, and particle density of $2.62 \mathrm{Mg} \mathrm{m}^{-3}$.

According to the area history prior to the installation of the coffee plantations, the soil was plowed and disking to a $40 \mathrm{~cm}$ deep and then harrowed. All equipment used in the coffee crop management was pulled by a Massey Ferguson 265 tractor, with a mass of about $3,940 \mathrm{~kg}$. The equipment used during a cropping season are fertilizer miname with approximate mass of $210 \mathrm{~kg}$ (3 passes per year), spray jet Arbus 400 Jacto with $400 \mathrm{~L}$ capacity and mass of $230 \mathrm{~kg}$ (3 passes per year), mower 
Kamaq with a mass of $340 \mathrm{~kg}$ ( 3 passes per year) and the spray jet PH 400 with $400 \mathrm{~L}$ capacity and mass of $210 \mathrm{~kg}$ (2 passes per year). Thus the total number of passes of the tractor per year is 11 on the same traffic line for each plot at different establishment times.

Samples were collected in this study in coffee plantations with different establishment times. They are 2 years (planted in 2008 with spacing $3.5 \mathrm{~m} \mathrm{x} 0.7 \mathrm{~m}$ - Cultivar Mundo Novo), 7 years (planted in 2003 with spacing $3.5 \mathrm{~m}$ x 0.9 m - Cultivate Paraíso MG), 18 years (planted in 1992 with spacing $3.5 \mathrm{~m} \times 1.0 \mathrm{~m}$ - Cultivate Mundo Novo) and 33 years (planted in 1977 with spacing $3.5 \mathrm{~m}$ x $2.0 \mathrm{~m}-$ Cultivate Catuaí Amarelo) of establishment. In these coffee plantations were selected areas (coffee row) with 3, 9 and $15 \%$ side slope (Figure 1). Sample were collected in three positions along the coffee row: bottom of traffic line (B), inter-row (I) and top traffic line (T) (Figure 1) at two depths: $0.00 \mathrm{~m}-0.03 \mathrm{~m}$ (Topsoil) and $0.15 \mathrm{~m}-0.18 \mathrm{~m}$ (Sub-surface). In total 72 conditions were collected (4 establishment times $\mathrm{x} 3$ slopes $\mathrm{x} 3$ positions $\mathrm{x} 2$ depths).

For evaluate the soil structure sustainability under the presented conditions and management were realized in this work, soil sampling in the field, uniaxial compression test of the samples in the laboratory and estimation of precompression stress to obtain the load bearing capacity (LBC) models. The detail as presented hereafter.

Soil Sampling - Undisturbed soil samples were collected in sampling rings measuring $2.54 \mathrm{~cm}$ in height and $6.40 \mathrm{~cm}$ diameter, which is compatible with the consolidation rings of the consolidometer. The rings were gently pushed into the soil with Uhland soil sampler. The collected samples are properly wrapped in waterproofplastic wrap and paraffin wax, to maintain the field moisture content and preserve the structures of the collected samples while being transported to the laboratory.

Uniaxial compression test - In order to procedure the uniaxial compression test in the undisturbed soil samples with controlled moisture content in the laboratory, the samples were saturated with distilled water by capillarity, and after 48 hours, the samples were dried in open air to obtain the different moisture contents. To obtain the different moisture contents, the soil samples were weighed on scales to achieve the weight corresponded to the required moisture. After reaching this desired moisture contents, the samples were used in uniaxial compression test according to the procedure of Bowles (1986) modified by Dias Junior and Pierce (1995). It was used the pneumatic S-450 Terraload floating ring consolidometer (Durham Geo Enterprises, USA) where loads are applied in form of pressure by compressed air. The levels of pressure applied to the soil samples were 25, 50, 100, 200, 400, 800 and 1600 $\mathrm{kPa}$, observing the assumption Taylor (1948), which defines the maximum deflection of up to $90 \%$ of the soil sample, for each pressure level.

Precompression stress estimation - plotting the values of deformation in the samples (void ratio or bulk density) against the logarithm of the pressure applied, it was obtained the soil compression curve, from wherein the precompression stress $\left(\sigma_{\mathrm{p}}\right)$ was estimated, observing the assumptions of method 1 or 3 , according to Dias Junior and Pierce (1995) which partition the methods depending on the soil moisture tension.

Constructing the load bearing capacity ( $L B C$ ) models - the precompression stress $\left(\sigma_{\mathrm{p}}\right)$ values was plotted as a function of the volumetric moisture content to which each sample was adjusted in the laboratory and it

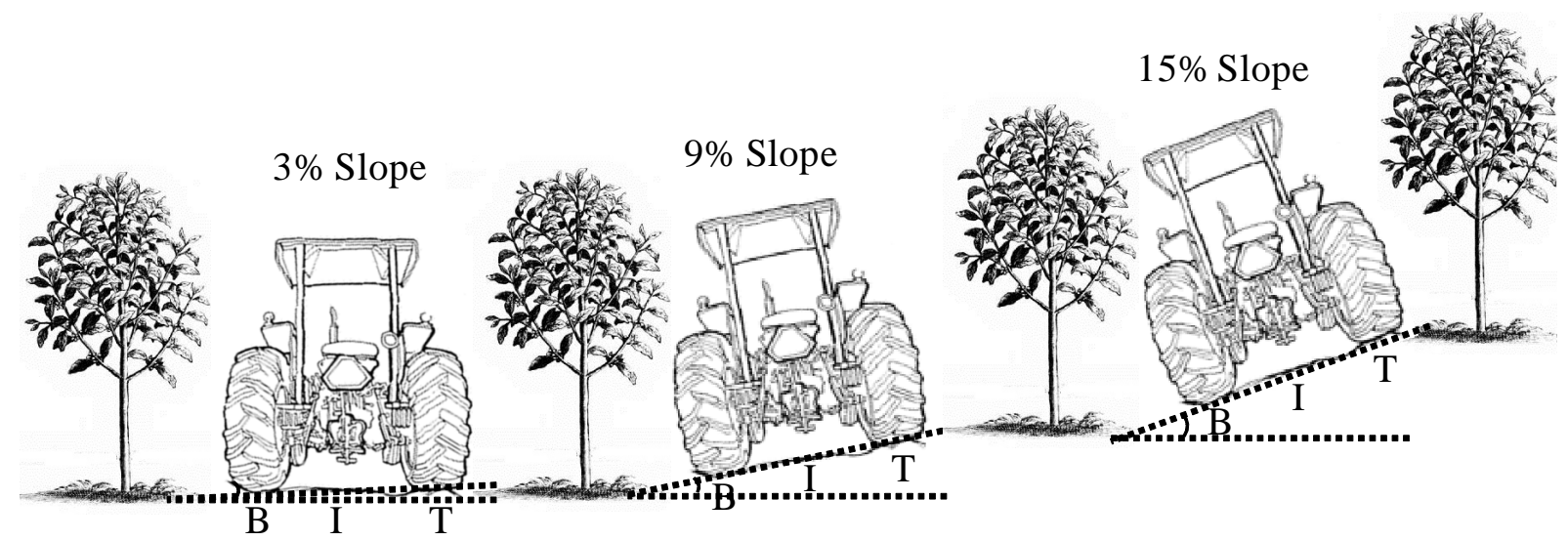

Figure 1 - Schematic representation of the sampling points in the coffee row with three side slope (3, 9 and $15 \%$ slope). B: bottom traffic line, I: inter-row and T: top traffic line.

Ciênc. agrotec., Lavras, v. 37, n. 2, p. 130-137, mar./abr., 2013 
was fitted the curves with the model (Equation 1) proposed by Dias Junior and Pierce (1995):

$\sigma_{\mathrm{p}}=10^{(\mathrm{a}+\mathrm{b} \theta)}$

Where, $\sigma_{\mathrm{p}}$ is precompression stress $(\mathrm{kPa}) ; \sigma$ is volumetric soil water content $\left(\mathrm{m}^{3} \mathrm{~m}^{-3}\right)$; a (linear coefficient or intercept) and b (angular coefficient) are empirical parameters for model adjustment. For laboratory model, it was used 14 soil samples $(n=14)$ collected in November 2010 for construction of each model. It was obtained one LBC models for reach 72 conditions considered in this study and the models are hereafter referred to as the "lab model".

For the construction of the field LBC models, "field model", it was followed the four steps earlier enumerated. The only difference was the soil samples were not saturated. The compression test was conducted on the soil at their natural "field" moisture content. However to ensure that the precompression stress are estimated at varying moisture content, it was collected samples round the year (October/2010 to September/2011), since the region had varying soil moisture status at different months reflective of the rainfall; distribution pattern (Figure 2). It was determined the precompression stress of 12 soil samples ( $n=12$, i.e. one sample per month) for the "field model" and also constructed one load bearing capacity model for reach 72 conditions in this study. Thus, in this study were used 1,872 total soil samples (12 soil samples for each "field model" and 14 soil samples for each "lab model" in 72 conditions).

After obtaining the soil LBC models for both laboratory and field conditions, it was compared all the "lab" models with the "field" models. The models were compared using the homogeneity test procedure of Snedecor and Cochran (1989). The procedure compares two linear models. To obtain linear models from the exponential model used in the construction of the LBC model (eq. 1), the logarithm model was linearized by finding the logarithm of both sides. In the test, the linear coefficient or intercept ("a") and the angular coefficient ("b") of the model equation were compared for homogeneity by $F$-test (ARAUJO-JUNIOR et al., 2011). When two models are homogenous and when there are no significance differences between their coefficients ("a" and "b"), the data can be pulled together and representative single model constructed (SNEDECOR; COCHRAN, 1989).

\section{RESULTS AND DISCUSSION}

All LBC models in this work presented significant exponential decay relationship for precompression stress with soil water content as similarly observed in several other studies (DIAS JUNIOR et al. 2005; AJAYI et al. 2010; ARAUJO-JUNIOR et al. 2011; MARTINS et al. 2012; PIRES et al. 2012). Table 1 presents the results of the significance test according to Snedecor and Cochran (1989) for the

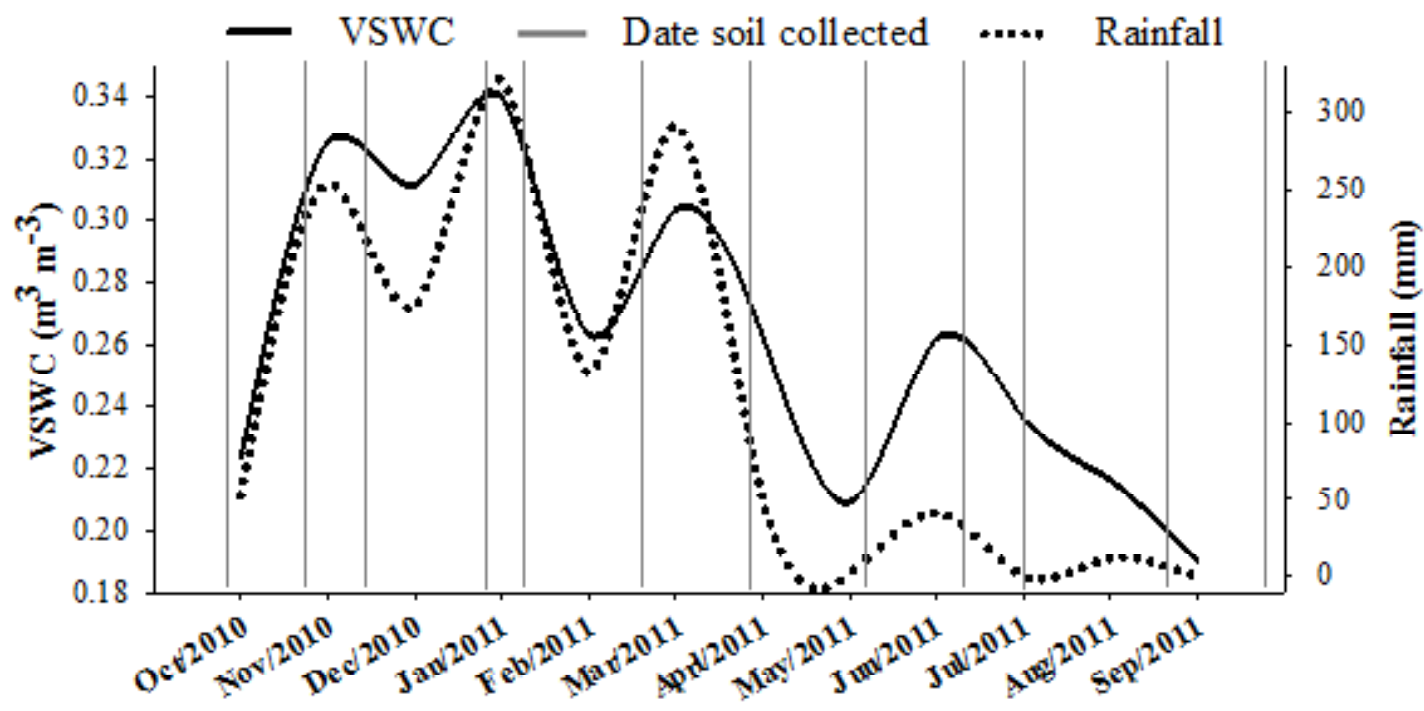

Figure 2 - Volumetric soil water content (VSWC) for different dates, rainfall data for study area and dates of each soil collect realized in 2010 and 2011. 
LBC models for "lab" and "field" soil samples. It was observed that $75 \%$ of field models analyzed were similar to lab models. Most of the field and lab models soil samples presented similar structure, resulting in equal LBC. This was similarly observed by Shafiq, Hassan and Ahmad (1994), in a comparison of laboratory and field measurements of some soil physical properties including penetration resistance and bulk density. They however observed that the laboratory measurement overpredicted the compaction compared to the field conditions. For these authors, their observation may be attributed to the differences in arrangement of soil pores under laboratory and field conditions as the soils disturbed and undisturbed respectively in the test. Similarly, Arvidsson (1998) obtained similar result in his work on field and laboratory compression experiments. He noted that compression was greater in the laboratory than in the field, and submitted that the differences may be due to the longer loading time in the uniaxial test machine, differences in settlement and relaxation cycle between soil types and differences in soil strength between the soil in the field and the disturbed soil used in the laboratory test.
The main difference for lab and field models was only between the "a" parameters. The $F$-test for data homogeneity and angular coefficient (b) between these models were not significant. Soil LBC models for lab and field had the same behavior. But, even on cases in that the models (lab and field) were similar, it was observed that the lab models had lower soil load support capacity when compared to the field model, in the other words, there were slight shift of field model in relation to lab model. It was observed that there was a slight upward shift for similar models. On the other hand, it was observed a strong upward shift for different models (lab and field). The upward shift indicates higher LBC and more soil compaction and this upward shift occurred for all models that it was analyzed. The soil sampling for lab models occurred in November/2010 but for field models the soil sampling occurred over a year (Since October/2010 to September/2011). Within the period of sampling collection (November/2010 - for "Lab" samples and Nov. 2010 until September/2011 - for "Field" samples) some field operations (trafficking of machine in the coffee plantations) never stopped. Because of this, there were

Table 1 - Comparison of LBC model $\left[\sigma_{\mathrm{p}}=10^{(\mathrm{a}+\mathrm{b} \theta)}\right]$ obtained from the field and laboratory model following the procedures of Snedecor and Cochran (1989).

\begin{tabular}{|c|c|c|c|c|c|c|c|c|c|c|c|c|c|c|}
\hline \multirow{4}{*}{$S$} & \multirow{4}{*}{$\mathrm{D}$} & \multirow{4}{*}{$\mathrm{P}$} & \multicolumn{12}{|c|}{ Years of establishment for coffee areas } \\
\hline & & & \multicolumn{3}{|c|}{2 years } & \multicolumn{3}{|c|}{7 years } & \multicolumn{3}{|c|}{18 years } & \multicolumn{3}{|c|}{33 years } \\
\hline & & & \multicolumn{12}{|c|}{ Comparison items } \\
\hline & & & $\mathrm{F}$ & $\mathrm{B}$ & $\mathrm{a}$ & $\mathrm{F}$ & $\mathrm{b}$ & $\mathrm{a}$ & $\mathrm{F}$ & $\mathrm{b}$ & a & $\mathrm{F}$ & $\mathrm{b}$ & $\mathrm{A}$ \\
\hline \multirow{6}{*}{3} & \multirow{3}{*}{ Top } & I & $\mathrm{H}$ & NS & NS & $\mathrm{H}$ & NS & $* *$ & $\mathrm{H}$ & NS & $* *$ & $\mathrm{H}$ & NS & NS \\
\hline & & $\mathrm{B}$ & $\mathrm{H}$ & NS & NS & $\mathrm{H}$ & NS & NS & $\mathrm{H}$ & NS & NS & $\mathrm{H}$ & NS & NS \\
\hline & & $\mathrm{T}$ & $\mathrm{H}$ & NS & NS & $\mathrm{H}$ & NS & NS & $\mathrm{H}$ & NS & NS & $\mathrm{H}$ & NS & NS \\
\hline & \multirow{3}{*}{ Sub } & I & $\mathrm{H}$ & NS & NS & $\mathrm{H}$ & NS & $* *$ & $\mathrm{H}$ & NS & NS & $\mathrm{H}$ & $* *$ & NS \\
\hline & & B & $\mathrm{H}$ & NS & NS & $\mathrm{H}$ & NS & $* *$ & $\mathrm{H}$ & NS & $* *$ & $\mathrm{H}$ & NS & NS \\
\hline & & $\mathrm{T}$ & $\mathrm{H}$ & NS & NS & $\mathrm{H}$ & NS & NS & $\mathrm{H}$ & NS & $* *$ & $\mathrm{H}$ & NS & NS \\
\hline \multirow{6}{*}{9} & \multirow{3}{*}{ Top } & I & $\mathrm{H}$ & NS & $* *$ & $\mathrm{H}$ & NS & NS & $\mathrm{H}$ & NS & NS & $\mathrm{H}$ & NS & NS \\
\hline & & B & $\mathrm{H}$ & NS & NS & $\mathrm{H}$ & NS & $* *$ & $\mathrm{H}$ & NS & NS & $\mathrm{H}$ & NS & NS \\
\hline & & $\mathrm{T}$ & $\mathrm{H}$ & NS & NS & $\mathrm{H}$ & NS & NS & $\mathrm{H}$ & NS & NS & $\mathrm{H}$ & NS & NS \\
\hline & \multirow{4}{*}{ Sub } & I & $\mathrm{H}$ & NS & NS & $\mathrm{H}$ & NS & NS & $\mathrm{H}$ & NS & NS & $\mathrm{H}$ & NS & NS \\
\hline & & B & $\mathrm{H}$ & NS & NS & $\mathrm{H}$ & NS & NS & $\mathrm{H}$ & NS & NS & $\mathrm{H}$ & NS & $* *$ \\
\hline & & $\mathrm{T}$ & $\mathrm{H}$ & NS & NS & $\mathrm{H}$ & NS & $* *$ & $\mathrm{H}$ & NS & $* *$ & $\mathrm{H}$ & NS & NS \\
\hline \multirow{6}{*}{15} & & I & $\mathrm{H}$ & NS & NS & $\mathrm{H}$ & NS & $* *$ & $\mathrm{H}$ & NS & $* *$ & $\mathrm{H}$ & NS & $* *$ \\
\hline & \multirow[t]{3}{*}{ Top } & B & $\mathrm{H}$ & NS & NS & $\mathrm{H}$ & NS & NS & $\mathrm{H}$ & NS & NS & $\mathrm{H}$ & NS & NS \\
\hline & & $\mathrm{T}$ & $\mathrm{H}$ & NS & NS & $\mathrm{H}$ & NS & NS & $\mathrm{H}$ & NS & NS & $\mathrm{H}$ & NS & NS \\
\hline & & I & $\mathrm{H}$ & NS & NS & $\mathrm{H}$ & NS & $* *$ & $\mathrm{H}$ & NS & NS & $\mathrm{H}$ & NS & NS \\
\hline & \multirow[t]{2}{*}{ Sub } & B & $\mathrm{H}$ & NS & NS & $\mathrm{H}$ & NS & NS & $\mathrm{H}$ & NS & $* *$ & $\mathrm{H}$ & NS & NS \\
\hline & & $\mathrm{T}$ & $\mathrm{H}$ & NS & NS & $\mathrm{H}$ & NS & NS & $\mathrm{H}$ & NS & $* *$ & $\mathrm{H}$ & NS & NS \\
\hline
\end{tabular}

S: slope (\%), D: depth, P: sampling position, Top: topsoil, Sub: sub-surface, I: inter-row, B: bottom traffic line, T: top traffic line, F: test for homogeneity; $b$ : angular coefficient, a: intercept, $\mathrm{H}$ : homogeneous, $* *$ : significant $(\mathrm{p}<0.01)$ e NS: not significant. 
changes in the structure of the soil and increase in the soil LBC in the coffee planted areas. In spite of these changes, $75 \%$ of the LBC, models analyzed were similar (Table 1). Modifications on soil structure due traffic machine in the coffee plantations were also observed by Miranda et al. (2003), Gontijo et al. (2008), Araujo-Junior et al. (2011), Carmo et al. (2011) and Martins et al. (2012).

It was compared the various parameters of the "lab" and "field" models in this study in other to fully understand the causative and magnitude of the differences or similarity. For the angular coefficient ("b" parameter equation 1), it was observed that only $1.4 \%$ of lab and field models analyzed were significantly different. The main differences between the models were obtained when compared the linear coefficient ("a" parameter equation 1), for this parameter, just $23.6 \%$ were significantly different.

The high level of similarity between the " $b$ " parameter (Table 1) that it was found in this study indicates that the parameter is more related to some factor of soil characteristics (mineralogy and texture) independent of the management or agricultural traffic. On the other hand, the almost total differences between lab and field models were observed on linear coefficient or intercept ("a" parameter equation 1). The results also indicate that the continuing machine operations promoted alteration in this parameter on field model in relation to lab model. Therefore, it was can conclude that the "a" parameter is influenced by soil management. According observations of Peng et al. (2004) using an exponential model similar $\left(\mathrm{Y}=\mathrm{a} \mathrm{e}^{\mathrm{bx}}\right.$; where, Y: precompression stress $(\mathrm{kPa})$; X: soil water content (\%); a and b: empirical parameters) to what it was presented here, the "b" parameter was related to the influences of soil attributes such as soil texture and the ("a") parameter values were higher for soil with higher bulk density indicating management influences on soil structure. Similarly the study by Araujo-Junior et al. (2011) related "a" coefficient to the packing state of the solid soil particles.

It was observed $94.4 \%$ of similarities between models for coffee plantation aged 2 years. For coffee plantation aged 33 years $83.3 \%$ of the models were similar. The highest differences between models were observed in coffee plantation aged 7 and 18 years. For these $61.1 \%$ models were similar. The higher percentage value of similarities between models was observed for coffee with 2 and 33 years of establishment, meaning the youngest and the oldest cultivated areas. The high similarity between models of coffee plantation aged 2 and 33 years results probably from the homogeneous soil condition for laboratory and field models. The soil compaction in these areas promoted a homogeneous soil condition between models, thus the difference between the models is not expressed in these compacted soils. Coffee plantation with 2 years of establishment presented higher soil compaction susceptibility due to soil tillage before of the coffee plantation establishment. Thus, the machine traffic in this soil susceptible promoted a soil compaction, resulting in similar soil structure between laboratory and field models. For coffee plantation aged 33 years, the similarity of the models observed also occurred due to equilibrium or stability conditions of these areas, because soil compaction. But, in this older areas (33 years) the soil compaction occurred as result of the accumulate traffic of agricultural machinery over the years.

It was observed also that similarity between models for different side slopes were very close. For the $3 \%$ side slope, $70.8 \%$ of the models were similar, for $9 \%$ side slope, $79.2 \%$ of the models were similar and for the $15 \%$ side slope $75 \%$ models were similar. When the models were compared for the sampling positions, it was observed that the similarity order was top traffic line > bottom traffic line $>$ inter-rows, with $83.3,79.2$ and $62.5 \%$, respectively. These results suggest that the more impact on soil structure happened in traffic lines, causing higher LBC than lines without traffic (inter-rows). Because of this, more difference between lab and field models was observed than on the inter-rows. Inter-rows have a structural condition that is more preserved, and any disturbance will cause notable structure alteration. Working on various sampling positions including traffic line and inter-rows, Miranda et al. (2003) and Gontijo et al. (2008) found a lower LBC on the inter-rows than on traffic lines.

At the topsoil $80.6 \%$ of the lab and field models were similar while in the sub-surface $69.4 \%$ of the models were similar. The biggest similarity between the models in the topsoil than sub-surface can be due to greater homogeneity of soil tillage in this layer. At greater depths, soil tillage may not have been as homogeneous as it was on the topsoil, may have provided variability in soil structure, resulting in these differences between laboratory models and field.

\section{CONCLUSIONS}

Load-bearing capacity models obtained with controlled moisture in laboratory are similar to models obtained with natural field moistures. Thus, due to the similarity between load-bearing capacity models, the assessment of the soil structure sustainability can be done using both methods. 


\section{ACKNOWLEDGEMENTS}

We sincerely appreciate the "Consórcio Brasileiro de Pesquisa e Desenvolvimento do Café CBP\&D/Café" and CAPES, FAPEMIG and CNPq for financial support for the research.

\section{REFERENCES}

AJAYI, A. E. et al. Assessment of vulnerability of Oxisols to compaction in the Cerrado Region of Brazil. Pedosphere, Nanjing, v.20, n.2, p.252-260, abr, 2010.

ARAUJO-JUNIOR, C. F. et al. Capacidade de suporte de carga e umidade crítica de um Latossolo induzida por diferentes manejos. Revista Brasileira de Ciência do Solo, Viçosa, v.35, n.1, p.115-131, jan./fev, 2011.

ARVIDSSON, J. Influence of soil texture and organic matter content on bulk density, air content, compression index and crop yield in field and laboratory compression experiments. Soil and Tillage Research, Amsterdam, v.49, n.1-2, p.159-170, nov, 1998.

ARVIDSSON, J.; KELLER, T. Soil precompression stress. I. A survey of Swedish arable soils. Soil and Tillage Research, Amsterdam, v.77, n.1, p.85-95, mai, 2004.

BOWLES, J.E. Engineering properties of soils and their measurements. 3. ed. New York: McGraw Hill, 1986, 218p.

CARMO, D.L. et al. Propriedades físicas de um Latossolo vermelho-amarelo cultivado com cafeeiro em três sistemas de manejo no sul de Minas Gerais. Revista Brasileira de Ciência doSolo, Viçosa, v.35, n.3, p.991998, mai./jun, 2011.

CASAGRANDE, A. The determination of preconsolidation load and its practical significance. Proceedings of the First International Conference on Soil Mechanics and Foundation Engineering, Cambridge, v.3, p.60-64, jun, 1936.

DIAS JUNIOR, M. S. et al. Traffic effects on the preconsolidation pressure due to eucalyptus harvest operations. Scientia Agricola, Piracicaba, v.62, n.3, p.248-255, mai./jun, 2005.

DIAS JUNIOR, M.S.; PIERCE, F.J. A simple procedure for estimating preconsolidation pressure from soil compression curves. Soil Technology, Amsterdam, v.8, n.2, p.139-151, nov, 1995.
DIAS JUNIOR, M.S. et al. Soil compaction due to forest harvest operations. Pesquisa Agropecuária Brasileira, Brasília, v.42, n.2, p.257-264, fev, 2007.

EMBRAPA-EMPRESA BRASILEIRADE PESQUISAS AGROPECUÁRIA. Sistema brasileiro de classificação de solos. Rio de Janeiro, 2006, 306 p.

GONTIJO, I. et al. Atributos físico-hídricos de um Latossolo de cerrado em diferentes posições de amostragem na lavoura cafeeira. Revista Brasileira de Ciência do Solo, Viçosa, v. 32, n. 6, p. 2227-2234, Nov./ Dez. 2008.

GREGORY, A.S. et al. Calculation of the compression index and precompression stress from soil compression test data. Soil and Tillage Research, Amsterdam, v.89, n.1, p.45-57, ago, 2006.

HAMILTON, J.J.; CRAWFORD, C.B. Improved determination of preconsolidation pressure of a sensitive clay. Proceedings of the American Society of Testing and Materials, Philadelphia, p. 254-271, 1959.

IORI, P.; DIAS JÚNIOR, M. S.; SILVA, R. B. Resistência do solo à penetração e ao cisalhamento em diversos usos do solo em áreas de preservação permanente.

Bioscience Journal, Uberlândia, v.28, supplement 1, p.185-195, mar, 2012.

IORI, P. et al. Pressão de preconsolidação como ferramenta de análise da sustentabilidade estrutural de Cambissolo Háplico, Argissolo Amarelo e Gleissolo Háplico em Registro, SP. Revista Brasileira de Ciência do Solo, Viçosa, v.36, n.5, p.1448-1456, set./ out, 2012.

KELLER, T. et al. Analysis of soil compression curves from uniaxial confined compression tests. Geoderma, Wageningen, v.163, n.1-2, p.13-23, jun, 2011.

\section{LEROUEILL, S.; SAMSON, L.; BOZOZUK, M.}

Laboratory and field determination of preconsolidation pressures at Gloucester. Canadian Geotechnical Journal, Birmingham, v.20, n.3, p.477-490, ago, 1983.

MARTINS, P.C.C. et al. Compaction caused by mechanized operations in a Red- Yellow Latosol cultivated with coffee over time. Ciência e Agrotecnologia, Lavras, v.36, n.4, p.391-398, jul./ago, 2012. 
MIRANDA, E.E.V. et al. Efeito do manejo e do tráfego nos modelos de sustentabilidade da estrutura de um Latossolo Vermelho cultivado com cafeeiros. Ciência e Agrotecnologia, Lavras, Edição Especial, p.1506-1515, 2003.

PENG, X.H. et al. Mechanisms of soil vulnerability to compaction of homogenized and recompacted Ultisols. Soil and Tillage Research, Amsterdam, v.76, n.2, p.125137, abr, 2004.

PIRES, B.S. et al. Modelos de capacidade de suporte de carga de um Latossolo Vermelho-amarelo sob diferentes usos e manejos. Revista Brasileira de Ciência do Solo, Viçosa, v.36, n.2, p.635-642, mar./abr, 2012.

SHAFIQ, M.; HASSAN, A.; AHMAD, S. Soil physical properties as influenced by induced compaction under laboratory and field conditions. Soil and Tillage

Research, Amsterdam, v.29, n.1, p.13-22, fev, 1994.

SNEDECOR, G. W.; COCHRAN, W. G. Statistical methods. 8. ed. Ames: Iowa State University Press. 1989, 503p.

TAYLOR, D. W. Fundamentals of soil mechanics. New York, John Wiley \& Sons, Inc., 1948, 700p. 